\title{
PENINGKATAN KOMPETENSI GURU SD DALAM MELAKSANAKAN PENELITIAN TINDAKAN KELAS
}

\section{Clara Ika Sari Budhayanti}

\author{
PGSD, Fakultas Pendidikan dan Bahasa Unika Atma Jaya \\ clara.ika@atmajaya.ac.id
}

\begin{abstract}
ABSTRAK
Salah satu kompetensi yang harus dimiliki guru SD/MI adalah kemampuan mengembangkan diri secara professional. Kemampuan mengembangkan diri secara professional dapat dilihat dari kemampuan dalam melaksanakan Penelitian Tindakan Kelas (PTK). Berdasarkan wawancara dengan tiga sekolah dasar di Kabupaten Cisauk, yaitu SDN Kedokan, SDN Cibogo, dan SDN Mekarwangi, jarang ada guru yang melakukan PTK. Dari 24 guru yang di ketiga sekolah tersebut hanya 7 guru yang pernah melaksanakan PTK, namun hanya 4 orang guru yang melaksanakan PTK untuk meningkatkan kualitas pembelajaran yang dilakukan. Sedangkan 3 guru lainnya melaksanakan PTK dalam rangka memenuhi salah satu tugas perkuliahan saat mengambil program sarjana. Oleh karena itu, Unika Atma Jaya melaksanakan Pelatihan Penelitian Tindakan Kelas bagi guru-guru di tiga SD tersebut. Setelah pelatihan guru diminta untuk menyusun draf proposal PTK. Pada dasarnya guru-guru telah dapat menentukan masalah dan alternatif pemecahan masalah yang akan diteliti, namun kebanyakan guru masih kesulitan menentukan fokus tindakan dan teknik pengumpulan data serta analisis data. Selain itu ada beberapa guru yang menuliskan latar belakang masalah penelitian tidak dilengkapi dengan landasan teori atau ada namun cara penulisannya salah. Draf proposal PTK yang telah disusun juga tidak memuat teori-teori secara lengkap sehingga tidak heran jika ketika menuliskan fokus tindakan, guru mengalami kesulitan. Dengan demikian, berdasarkan hasil tersebut dapat disimpulkan bahwa secara konseptual, guru-guru telah memahami bagaimana melaksanakan PTK namun dalam praktik guru-guru tersebut masih mengalami kesulitan terutama dalam menentukan dan mengembangkan instrumen penelitian sebagai alat pengumpul data serta bagaimana cara mengolahnya menjadi data penelitian. Oleh karena itu, disarankan perlu adanya pendampingan dalam pengembangan instrumen penelitian serta dalam pelaksanaan penelitian tindakan kelasnya.
\end{abstract}

Kata Kunci : Kompetensi Guru, Penelitian Tindakan Kelas

\section{PENDAHULUAN}

Guru memiliki peran yang sangat strategis dalam pendidikan. Peranan strategis tersebut terjadi pada setiap upaya peningkatan mutu, relevansi, dan efisiensi pendidikan. Penyelenggaraan dan keberhasilan proses pendidikan sangat ditentukan oleh faktor guru. Guru menjadi penentu utama dalam mewujudkan fungsi dan tujuan pendidikan nasional seperti yang tercantum dalam UndangUndang Republik Indonesia Nomor: 20 Tahun 2003 tentang Sistem Pendidikan Nasional, Bab II Pasal 3 yaitu mengembangkan kemampuan dan membentuk watak serta peradaban bangsa yang bermartabat dalam rangka mencerdaskan kehidupan bangsa, bertujuan untuk berkembangnya potensi peserta didik agar menjadi manusia yang beriman dan bertakwa kepada Tuhan Yang Maha Esa, berakhlak mulia, sehat, berilmu, cakap, kreatif, mandiri, dan menjadi warga negara yang demokratis serta bertanggung jawab. Tujuan pendidikan nasional ini tidak akan tercapai apabila tidak didukung oleh kinerja guru yang kompeten dan professional serta memiliki kapasitas di bidangnya sehingga guru mampu berperan secara maksimal dalam proses pendidikan. Sebagaimana tertuang dalam Undang-Undang Republik Indonesia Nomor 14 Tahun 2005 tentang Guru dan Dosen Pasal 2 ayat (1) ditegaskan bahwa guru mempunyai kedudukan sebagai tenaga profesional pada jenjang pendidikan dasar, pendidikan menengah, dan pendidikan anak usia dini pada jalur pendidikan formal yang diangkat sesuai dengan peraturan perundang-undangan. Guru sebagai tenaga professional sebagaimana dimaksud dalam pasal tersebut berfungsi untuk meningkatkan martabat dan peran guru sebagai agen pembelajaran berfungsi untuk meningkatkan mutu pendidikan nasional. 
Guru profesional menurut Cahyana (2010) adalah guru yang dapat menjalankan tugasnya secara profesional, yang memiliki ciri-ciri yaitu ahli di bidang keguruan baik teori maupun praktek, bergabung dengan organisasi profesi keguruan, memiliki latar belakang pendidikan keguruan, melaksanakan kode etik guru, memiliki otonom dan rasa tanggungjawab, mempunyai semangat untuk mengabdikan diri kepada masyarakat, dan bekerja atas panggilan hati nurani. Guru yang profesional adalah guru yang memiliki kemampuan yang maksimal dalam melaksanakan tugas jabatan guru secara maksimal, baik secara konseptual maupun aplikatif (Pidarta, 2011). Guru yang profesional ditunjang oleh penguasaan ilmu tertentu secara mendalam yang hanya mungkin diperoleh dari lembaga-lembaga pendidikan yang sesuai sehingga kinerjanya didasarkan kepada keilmuan yang dimilikinya dan dapat dipertanggung jawabkan secara ilmiah (Suyanto, 2012). Jadi seorang guru yang professional wajib memiliki kemampuan khusus yang tidak mungkin dimiliki oleh orang yang bukan guru dan yang tidak melalui pendidikan keguruan. Oleh karena itu profesi guru bukanlah profesi yang mudah. Tuntutan pekerjaan guru kadang dirasa lebih berat dibandingkan profesi lain. Guru harus selalu menampilkan kepribadian secara utuh sebagai guru. Guru merupakan seorang yang harus bisa digugu dan ditiru (Mulyasa, 2005). Digugu artinya segala sesuatu yang disampaikan senantiasa dipercaya dan diyakini sebagai kebenaran oleh semua peserta didiknya. Segala ilmu pengetahuan yang datangnya dari sang guru dijadikan sebagai sebuah kebenaran yang tidak perlu dibuktikan atau diteliti lagi sedangkan ditiru artinya ia menjadi suri teladan dan panutan bagi peserta didiknya, mulai dari cara berpikir, cara berbicara hingga cara berperilaku sehari-hari. Dengan demikian, guru memiliki peran yang sangat besar dalam pelaksanaan pembelajaran atau pendidikan.

Tuntutan terhadap profesi guru kian menantang dengan dengan adanya perubahan jaman diberbagai bidang. Pendidikan saat ini dituntut agar mampu bergerak secara fleksibel mengikuti pergerakan dan perkembangan global yang terjadi di dunia. Perubahan yang sangat cepat tidak terelakkan terutama di bidang teknologi, informasi, seni, dan budaya. Perubahan global ini menjadi tantangan bagi guru untuk lebih meningkatkan kinerja secara terus menerus agar dapat menyiapkan peserta didik yang menjadi tanggungjawabnya mampu menghadapi permasalahan global yang terjadi. Peningkatan profesionalisme guru juga tidak terelakkan karena guru berperan untuk dapat mewujudkan tujuan pendidikan nasional khususnya dalam mengembangkan kemampuan dan membentuk watak peserta didik sehingga kelak menjadi sumber daya manusia yang berkualitas dan handal. Selain itu peningkatan profesionalisme guru merupakan suatu keharusan bagi setiap guru karena guru memiliki kewajiban untuk selalu memperbaiki dan meningkatkan kualitas pendidikan.

Upaya peningkatan professional guru dapat dilakukan dari berbagai pihak. Menurut Zamania (2009) upaya peningkatan kompetensi guru dilakukan oleh guru, kepala sekolah atau lembaga. Peningkatan yang dapat dilakukan oleh guru itu sendiri antara lain dengan mengikuti penataran dan mengikuti seminar/diskusi, atau dengan memanfaatkan media cetak atau media massa dan media elektronik. Sedangkan peningkatan profesionalisme guru yang dilakukan oleh lembaga pendidikan antara lain dengan mengadakan lokakarya (workshop) atau pelatihan, mendukung ideide baru dari guru dengan berbagai lomba atau seminar, memotivasi guru untuk membuat karya tulis ilmiah, atau memberikan penghargaan (reward) pada guru berprestasi. Upaya yang sering dilakukan guru bekerjasama dengan lembaga pendidikan adalah mengikuti pelatihan. Pelatihan yang dimaksud adalah pelatihan yang berhubungan dengan pelaksanaan tugas guru terutama sekali dalam pelaksanaan pembelajaran, sehingga setelah mengikuti pelatihan tersebut diharapkan guru memiliki pengalaman, keterampilan, dan pengetahuan baru tentang berbagai permasalahan pelaksanaan tugas guru baik yang berhubungan dengan penguasaan materi pelajaran, penguasaan metode, kendala-kendala yang dihadapi dalam pelaksanaan pembelajaran termasuk upaya 
penanggulangannya, dan permasalahan yang berhubungan dengan pelaksanaan evaluasi atau penilaian hasil pembelajaran para siswa. Upaya penanggulangan kendala-kendala dalam pelaksanaan pembelajaran dapat dilakukan melalui Penelitian Tindakan Kelas (PTK). Penelitian Tindakan Kelas (PTK) merupakan upaya guru dalam merasionalkan semua tindakan pembelajaran yang dilakukan untuk memperbaiki atau meningkatkan kualitas proses pembelajaran. Hal ini sesuai dengan pendapat Mulyasa (2005) yang menyatakan bahwa PTK bertujuan untuk memperbaiki dan meningkatkan kondisi serta kualitas pembelajaran dikelas. Peningkatan kualitas pembelajaran dapat dilakukan guru dengan cara mencermati setiap tindakan pembelajaran dengan mengajukan pertanyaan menyelidik seperti, apakah penggunaan metode, strategi, pemilihan media, sarana, serta pengelolaan kelas efektif mempercepat pencapaian kompetensi peserta didik. Proses menemukan jawaban dari pertanyaan-pertanyaan tersebut serta bagaimana memperbaikinya harus menjadi komitmen guru sebagai seseorang yang professional. Pengajuan pertanyaan dan proses menemukan jawaban dari pertanyaan tersebut merupakan bagian dari kegiatan penelitian khususnya Penelitian Tindakan kelas (PTK). Dengan demikian PTK merupakan salah satu cara mengembangkan profesionalisme guru sesuai dengan pendapat Mulyasa (2009) yang menyatakan bahwa PTK bermanfaat bagi guru untuk meningkatkan profesionalisme guru melalui upaya penelitian yang dilakukannya. Hal senada diungkapkan oleh Iskandar (2012) yang menyatakan bahwa PTK merupakan salah satu tugas dalam pengembangan profesi guru.

Peningkatan kompetensi professional khususnya dalam melaksanakan penelitian Tindakan Kelas (PTK) akan lebih efektif dan efisien apabila peningkatan kompetensi ini disuport oleh lembaga pendidikan. Oleh karena itu diperlukan adanya kerjasama antara lembaga pendidikan, supervisi sekolah, dan guru serta kesadaran dalam diri seorang guru tersebut untuk meningkatkan profesionalismenya. Salah satu bentuk kegiatannya adalah pelatihan kepada guru sehingga dapat meningkatkan kompetensi guru dalam melaksanakan Penelitian Tindakan Kelas (PTK). Program Studi Pendidikan Guru SD (PGSD) dari Fakultas Pendidikan dan Bahasa (FPB) Unika Atma Jaya memiliki kapasitas dalam melaksanakan PTK serta dalam memberikan pelatihan kepada guru SD di beberapa sekolah mitra seperti SD Santa Theresia, sekolah-sekolah di bawah Yayasan Tarsisius, dan juga sekolah-sekolah di bawah Yayasan Strada. Pelatihan ini merupakan salah satu bentuk kontribusi prodi dalam upaya peningkatan kualitas pendidikan sekolah dasar di Indonesia. Berdasarkan pengalaman dalam memberikan pelatihan pelaksanaan PTK di sekolah-sekolah tersebut, tidak banyak guru yang melaksanakan PTK setelah diberikan pelatihan. Hal ini disebabkan karena para guru tersebut masih belum memahami bagaimana pelaksanaan PTK secara praktis. Oleh karena itu, peningkatan kompetensi professional guru khususnya dalam melaksanakan PTK diselenggarakan dengan menggunakan kombinasi metode yaitu pelatihan dan pendampingan.

Pelatihan dan pendampingan ini diberikan kepada guru-guru SD di daerah Tangerang yang berjumlah 24 orang guru dari 3 sekolah dasar yang berbeda, yaitu dari SDN Cibogo, SDN Kedokan, dan SDN Mekarwangi. Ketiga SD tersebut merupakan sekolah negeri dengan jumlah guru yang terbatas. SDN Kedokan memiliki 14 guru dan SDN Cibogo memiliki 5 guru yang semuanya S-1. Sedangkan SDN Mekar Wangi merupakan sekolah negeri yang baru berdiri 2013 dengan hanya memiliki enam guru dengan pendidikan terakhir S-2 sebanyak satu guru, S-1 empat guru dan masih ada satu guru yang sedang dalam proses pendidikan S-1. Sasaran pelatihan dan pendampingan ini terdiri dari 24 guru. Berikut distribusi frekuensi guru dari ketiga sekolah tersebut.

Tabel 1. Distribusi Frekuensi Peserta Pelatihan 


\begin{tabular}{|c|l|c|}
\hline No. & \multicolumn{1}{|c|}{ Nama Sekolah } & Jumlah \\
\hline 1 & SDN Cibogo & 7 \\
\hline 2 & SDN Kedokan & 11 \\
\hline 3 & SDN Mekarwangi & 6 \\
\hline & Total & 24 \\
\hline
\end{tabular}

Rata-rata guru SD dari ketiga sekolah tersebut belum pernah melaksanakan Penelitian Tindakan Kelas (PTK). Guru yang sudah pernah melaksanakan PTK sebanyak 7 orang atau sekitar 29\% dari keseluruhan peserta. Bahkan 3 dari 7 guru tersebut, melaksanakan PTK sebagai tugas akhir saat mengikuti program sarjana. Sementara terdapat 2 guru yang melaksanakan PTK dikarenakan untuk memenuhi syarat kenaikan jabatan. Semua guru yang pernah melaksanakan PTK mengatakan bahwa mereka belum pernah mempublikasikan hasil penelitiannya, baik dalam bentuk seminar maupun jurnal ataupun buku. Guru-guru yang belum pernah melaksanakan PTK mengatakan bahwa mereka tidak melakukan PTK karena belum memahami dengan baik bagaimana melaksanakan PTK. Oleh karena itu mereka sangat mengharapkan bukan saja Pelatihan Pelaksanaan PTK tetapi juga pendampingan dalam melaksanakannya. Selain kurang memahami bagaimana melaksanakan PTK, guru tidak memiliki kesempatan untuk melakukan PTK karena memiliki banyak tugas dan tanggung jawab, seperti membimbing siswa untuk berprestasi, mengerjakan pekerjaan administrasi, membuat RPP, dan lain sebagainya. Rata-rata golongan guru-guru tersebut tidak lebih dari IIIB. Alasan para guru enggan mengurus kenaikan golongan karena persyaratan administrasi yang terlalu banyak, ditambah dengan kurangnya keterampilan dalam menulis artikel PTK. Terlepas dari kebutuhan personal sebagai guru dalam memenuhi prasyarat kenaikan golongan, kemampuan menulis karya ilmiah dari hasil PTK merupakan "bagian penting dari upaya pengembangan profesi guru karena mampu membelajarkan guru untuk berpikir kritis dan sistematis serta membelajarkan guru untuk menulis" (Sumini, 2010). Oleh karena itu, pelatihan dan pendampingan guru yang dilakukan diharapkan mampu meningkatkan kemampuan guru dalam melaksanakan Penelitian Tindakan Kelas (PTK)

\section{TINJAUAN PUSTAKA}

Kompetensi guru dapat diartikan sebagai kewenangan dan kecakapan atau kemampuan seseorang dalam melaksanakan tugas atau pekerjaan sesuai dengan jabatan yang disandangnya yaitu sebagai guru. Kompetensi terwujud dalam bentuk penguasaan pengetahuan, keterampilan, dan sikap profesional dalam menjalankan fungsi sebagai guru. Oleh karena itu penjelasan kompetensi guru selanjutnya dituangkan dalam peraturan menteri Pendidikan Nasional No 16 tahun 2007 tentang kualifikasi akademik dan kompetensi guru yang berbunyi bahwa setiap guru wajib memenuhi kualifikasi akademik dan kompetensi guru yang berlaku secara nasional. Kualifikasi akademik Guru atau bentuk lain yang sederajat, harus memiliki kualifikasi akademik pendidikan minimum diploma empat (D-IV) atau sarjana (S1) dalam bidang pendidikan (D-IV/S1) yang diperoleh dari program studi yang terakreditasi. Kompetensi yang dimiliki oleh guru akan menunjukkan kualitas guru yang sebenarnya. Guru yang berkualitas diharapkan mampu menghasilkan peserta didik yang berkualitas pula. Perlu adanya jaminan dikuasainya tingkat kompetensi minimal oleh guru sehingga yang bersangkutan dapat melakukan tugasnya secara profesional, dapat memperoleh binaan secara efektif dan efisien, serta dapat melayani pihak yang berkepentingan terhadap proses pembelajaran dengan sebaik-baiknya sesuai dengan bidang tugasnya. Oleh karena itu perlu ada standar kompetensi guru sebagai suatu pernyataan tentang kriteria yang dipersyaratkan, ditetapkan, dan disepakati bersama dalam bentuk penguasaan pengetahuan, keterampilan, dan sikap bagi seorang tenaga kependidikan sehingga layak disebut kompeten. Kompetensi guru yang tertuang dalam Undang-undang No.14 tahun 2005 tentang Guru dan Dosen pasal 10 ayat (1) 
meliputi kompetensi pedagogik, kompetensi kepribadian, kompetensi sosial, dan kompetensi professional. Keempat kompetensi tersebut terintegrasi dalam kinerja guru. Kompetensi pedagogik merupakan kemampuan guru yang berkenaan dengan pemahaman terhadap peserta didik dan pengelolaan pembeajaran mulai dari merencanakan, melaksanakan sampai dengan mengevaluasi. Kompetensi kepribadian merupakan personal yang mencerminkan kepribadian yang mantap, stabil, dewasa, arif dan berwibawa menjadi teladan bagi peserta didik dan berakhlak mulia. Kompetensi sosial berkenaan dengan kemampuan pendidik sebagai bagian dari masyarakat untuk berkomunikasi dan bergaul secara efektif dengan peserta didik, sesama pendidik, tenaga kependidian, orang tua siswa, dan masyarakat sekitar. Kompetensi professional merupakan kemampuan yang berkenaan dengan penguasaan materi pembelajaran secara luas dan mendalam yang mencakup penguasaan substansi isi materi pembelajaran, dan substansi keilmuan yang menaungi materi dalam kurikulum, serta menambah wawasan keilmuan.

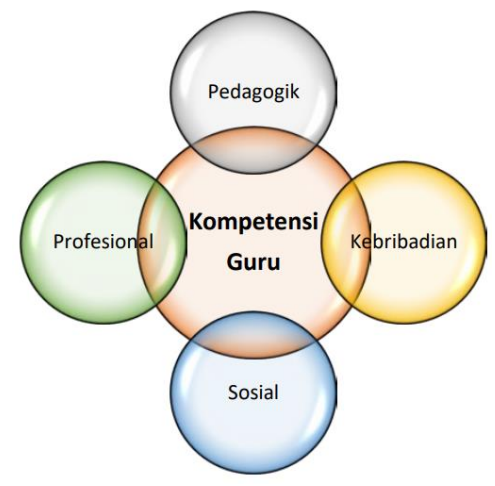

Gambar 1. Kompetensi Guru

Setiap kompetensi di atas dijabarkan dalam subkompetensi. Salah satu subkompetensi professional adalah mengembangkan keprofesionalan secara berkelanjutan dengan melakukan tindakan reflektif, seperti (1) melakukan refleksi terhadap kinerja sendiri secara terus-menerus, (2) memanfaatkan hasil refleksi dalam rangka peningkatan keprofesionalan, (3) melakukan penelitian tindakan kelas untuk peningkatan keprofesionalan, (4) mengikuti kemajuan zaman dengan belajar dari berbagai sumber. Pada subkompetensi tersebut dengan jelas dikatakan bahwa guru harus melakukan Penelitian Tindakan Kelas (PTK) untuk peningkatan keprofesionalan. Dengan kata lain guru yang melakukan PTK adalah guru yang terus berupaya meningkatkan kompetensinya sebagai seorang guru hingga menjadi guru yang professional. Hal ini sesuai dengan pendapat Asmarani (2014) yang menyatakan bahwa salah salah satu upaya peningkatan kompetensi professional yang dapat dilakukan oleh guru adalah dengan melakukan Penelitian Tindakan Kelas (PTK). PTK adalah suatu penelitian yang bersifat reflektif dan cukup efektif karena dapat dilakukan tanpa harus meninggalkan tugas mengajar. Penelitian Tindakan Kelas (PTK) adalah penelitian tindakan yang dilakukan oleh guru dengan tujuan untuk memperbaiki mutu pelaksanaan pembelajaran di kelasnya (Suparno, 2008). Oleh karena tujuan PTK adalah memperbaiki kualitas proses pembelajaran, maka kegiatan yang dilakukan haruslah berupa tindakan yang diyakini lebih baik dari kegiatan-kegiatan yang biasa dilakukan. Dengan kata lain, tindakan yang diberikan kepada siswa harus terlihat lebih efektif, efisien, kreatif dan inovatif.

Hal ini dikarenakan PTK memiliki karakteristik yaitu, (1) masalah yang diangkat untuk dipecahkan dan kondisi yang diangkat untuk ditingkatkan harus berangkat dari praktik pembelajaran nyata di sekolah; (2) guru dapat meminta bantuan orang lain untuk mengenal dan mengelaborasi masalah yang akan dijadikan topik penelitian (Mulyasa, 2005). Penelitian Tindakan kelas selain dapat meningkatkan profesionalisme guru, melalui upaya penelitian yang dilakukannya, juga bermanfaat untuk mengembangkan dan melakukan inovasi pembelajaran yang 
merupakan upaya pengembangan kurikulum di tingkat kelas. Karakteristik utama dari PTK adalah sifatnya yang siklis. Desain PTK menurut Tripp dalam Subyantoro (2010) disajikan pada gambar berikut.

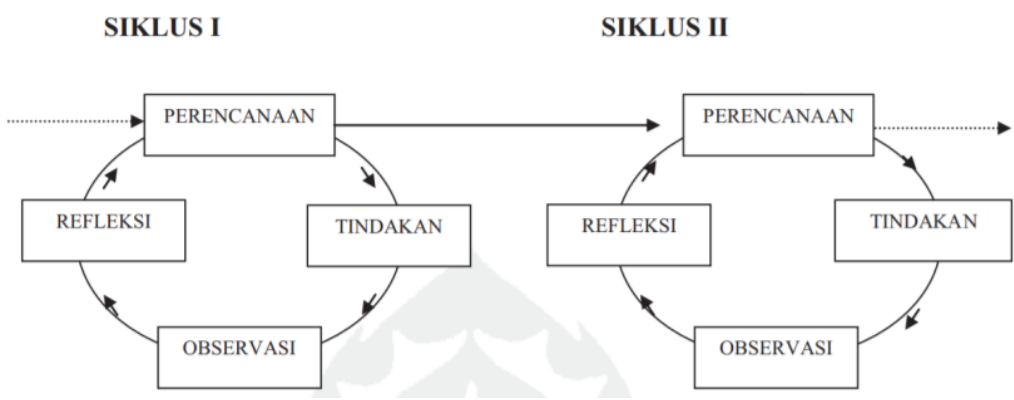

Gambar 2. Desain PTK

Pada bagian perencanaan, kegiatan yang dilakukan adalah merancang penelitian tindakan yang akan dilakukan. Kalau pelaksanaannya di kelas berarti rencana/perencanaan tersebut disesuaikan dengan objek dan masalah yang ditingkatkan. Selanjutnya pada tahap tindakan Pada tahap tindakan, kegiatan yang dilakukan adalah melaksanakan intervensi sesuai dengan rencana yang telah disusun. Tindakan dilaksanakan dengan hati-hati dan teliti agar dicapai peningkatan yang baik. Pada tahap pengamatan atau observasi, kegiatan yang dilakukan adalah mengamati dampak tindakan yang dilakukan. Apakah rencana dan tindakannya berhasil atau tidak. Artinya apakah ketika proses ada peningkatan atau tidak (peningkatan motivasi/semangat, peran, dan hasil). Sedangkan pada tahap refleksi, kegiatan yang dilakukan adalah membuka dan membahas kembali terhadap apa yang telah dilakukan. Refleksi di sini untuk mengetahui kekurangan, kelemahan dan ketidakberhasilan tindakan yang telah dilakukan kemudian menyusun rekomendasi dan saran-saran untuk melangkah pada siklus berikutnya jika belum tuntas.

\section{METODE PELAKSANAAN}

Pelaksanaan pelatihan dan pendampingan Penelitian Tindakan Kelas (PTK) diselenggarakan dalam tiga tahapan yaitu tahap persiapan, pelaksanaan, dan tahap evaluasi. Pada tahap persiapan, dilakukan dengan penyusunan modul pelatihan PTK dan instrumen persepsi guru terhadap pelaksanaan PTK. Instrumen disusun berdasarkan dimensi persepsi yang dikemukakan oleh Calhoun dan Acocella (1995) dalam Herlina (2008) yaitu dimensi pengetahuan, pengharapan, dan evaluasi. Sebelum tahap pelaksanaan, peserta pelatihan diminta untuk mengisi instrumen persepsi guru terhadap pelaksanaan PTK. Selanjutnya pada tahap pelaksanaan, terdiri dari dua subkegiatan yaitu subkegiatan pertama adalah pelatihan pelaksanaan PTK yang disampaikan dengan metode ceramah, diskusi, demonstrasi (bedah contoh), latihan, presentasi peserta, serta praktik. Pelatihan diselenggarakan sebanyak dua kali pertemuan. Pada saat pelatihan, guru dibagi dalam kelompok berdasarkan kelas. Setiap kelompok terdiri atas dua hingga tiga orang. Adapun materi yang disampaikan dalam pelatihan PTK meliputi pengenalan PTK, prosedur PTK, penulisan proposal PTK, serta penyusunan perangkat pembelajaran (RPP, LKS, lembar observasi, soal tes). Subkegiatan kedua adalah pendampingan yang meliputi kegiatan memonitor, mengarahkan, dan membimbing guru dalam melaksanakan PTK. Pendampingan ini diadakan tiga kali pertemuan. Pada tahap evaluasi, dilakukan penilaian terhadap proposal PTK yang sudah disusun guru.

\section{HASIL PELATIHAN DAN PENDAMPINGAN DALAM MELAKSANAKAN PTK}

Sebelum melaksanakan Pelatihan Pelaksanaan PTK, peserta diminta mengisi kuisioner mengenai persepsi mereka terhadap PTK. Hasil kuisioner diharapkan dapat memberikan gambaran 
bagaimana pandangan mereka terhadap PTK. Hasil kuisioner menunjukkan bahwa pada dasarnya guru-guru tersebut memiliki persepsi atau pandangan yang baik terhadap PTK. Hal ini dibuktikan dengan rata-rata skor sebesar 2,88 yang termasuk dalam kategori baik. Kuisioner persepsi ini disusun dengan mengacu pada tiga aspek persepsi yaitu aspek pengetahuan, harapan, dan evaluasi. Pada aspek pengetahuan, rata-rata skor yang diperoleh adalah 2,61 yang masih termasuk dalam kategori baik, namun rata-rata skor ini terletak di bawah rentang skor untuk kategori baik. Jadi dapat disimpulkan bahwa, persepsi guru terhadap PTK dilihat dari aspek pengetahuan cukup baik. Hal ini berarti pada dasarnya guru memahami dengan cukup baik bagaimana konsep dasar, prinsip, dan karakteristik serta bagaimana pelaksanaan PTK secara konseptual. Pada aspek harapan, ratarata skor yang diperoleh paling tinggi diantara aspek yang lain, yaitu sebesar 3 dengan kategori baik. Rata-rata skor ini menunjukkan bahwa para guru tersebut memiliki harapan yang besar untuk dapat melaksanakan PTK. Sedangkan dari aspek evaluasi terhadap pelaksanan PTK, diperoleh rata-rata skor sebesar 2,61 yang posisinya sama dengan rata-rata skor pada aspek pengetahuan. Rata-rata skor ini menunjukkan bahwa guru-guru tersebut menyadari bahwa mereka masih kurang memahami pelaksanaan PTK baik secara prosedural maupun praktik.

Pelatihan dilakukan sebanyak dua kali pertemuan. Masing-masing pertemuan dilaksanakan selama 5 jam. Pertemuan pertama dilaksanakan di SDN Kedokan dan pertemuan kedua dilaksanakan di SDN Mekarwangi. Hari pertama pelatihan dilaksanakan pada Sabtu, 1 September 2018. Pelatihan dilaksanakan mulai pukul 10.00 sampai dengan 15.00. Pelatihan dimulai dengan pemberian materi mengenai konsep dasar Penelitian Tindakan Kelas (PTK). Di sela-sela pemberian materi guru diajak berdiskusi. Pada saat diskusi terkadang para guru kesulitan memberikan jawaban yang diminta oleh narasumber seperti saat diminta untuk menggali masalah yang dapat menjadi masalah penelitian. Kebanyakan guru mengungkapkan masalah yang sulit untuk diselesaikan melalui PTK atau masalah-masalah individual siswanya. Selain itu guru lebih fokus pada permasalahan yang dialami oleh siswa namun kurang menggali masalah dari aspek guru. Oleh karena itu narasumber merubah strategi penyampaian dengan menggunakan metode diskusi kelompok. Peserta pelatihan dibagi menjadi 6 kelompok berdasarkan kelas yang diampunya. Berikut distribusi peserta dalam setiap kelompok.

Tabel 2. Distribusi Peserta Pelatihan dalam Kelompok

\begin{tabular}{|c|c|}
\hline Kelas & Jumlah Guru \\
\hline I & 5 \\
\hline II & 5 \\
\hline III & 4 \\
\hline IV & 3 \\
\hline V & 2 \\
\hline VI & 4 \\
\hline Jumlah Total & 23 \\
\hline
\end{tabular}

Saat diskusi dalam kelompok dengan kelas yang sama, nampak guru mulai banyak mengungkapkan permasalahan yang dialaminya di kelas. Karena situasi yang ditemukan pada saat pelatihan, maka ada perubahan rencana pelaksanaan penelitian tindakan kelasnya. Pada awalnya, PTK akan dilaksanakan secara individu, namun melihat hasil pengamatan pada saat pelatihan, narasumber memutuskan untuk meminta guru-guru tersebut melaksanakan PTK secara kolaboratif dengan guru yang mengampu kelas yang sama. Kemudian setiap kelompok diminta untuk memberikan alternatif penyelesaian masalah. Kebanyakan guru kurang dapat menjelaskan dengan baik. Biasanya mereka memberikan alternatif penyelesaian masalah berdasarkan pengalaman. Ketika ditanyakan, dasar atau acuan alternatif tersebut, mereka kurang mengetahui karena mereka kurang mengikuti perkembangan pembelajaran yang ada. Oleh karena itu, narasumber membantu 
menentukan dasar teori yang sesuai dengan cara atau metode yang mereka gunakan dalam menyelesaikan masalah pembelajaran tersebut. Berikut hasil diskusi mengenai masalah dan alternatif penyelesaian masalah yang dinyatakan dalam judul penelitian tindakan kelas.

Tabel 3. Daftar Judul Penelitian Tindakan Kelas

\begin{tabular}{|c|c|c|c|}
\hline $\begin{array}{l}\text { KELA } \\
\text { S }\end{array}$ & MASALAH & $\begin{array}{c}\text { PENYELESAIAN } \\
\text { MASALAH }\end{array}$ & JUDUL PENELITIAN \\
\hline \multirow{2}{*}{$\mathrm{I}$} & \multirow{2}{*}{$\begin{array}{l}\text { Kesulitan } \\
\text { membaca }\end{array}$} & $\begin{array}{l}\text { Dengan metode } \\
\text { abjad }\end{array}$ & $\begin{array}{c}\text { Peningkatan kemampuan membaca } \\
\text { permulaan dengan menggunakan metode } \\
\text { abjad di kelas I SDN Kedokan }\end{array}$ \\
\hline & & Metode suku kata & $\begin{array}{l}\text { Peningkatan kemampuan membaca } \\
\text { permulaan dengan menggunakan metode } \\
\text { suku kata di kelas I SDN Mekarwangi }\end{array}$ \\
\hline II & Minat belajar & $\begin{array}{c}\text { Media } \\
\text { pembelajaran }\end{array}$ & $\begin{array}{l}\text { Peningkatan minat belajar siswa pada } \\
\text { pelajaran matematika dengan } \\
\text { menggunakan media pembelajaran di } \\
\text { kelas II SDN Kedokan }\end{array}$ \\
\hline \multirow{2}{*}{ III } & \multirow{2}{*}{$\begin{array}{l}\text { Keaktifan } \\
\text { belajar }\end{array}$} & Metode diskusi & $\begin{array}{c}\text { Upaya meningkatkan keaktifan belajar } \\
\text { siswa dengan metode diskusi di kelas III } \\
\text { SDN Cibogo }\end{array}$ \\
\hline & & Metode kompetisi & $\begin{array}{c}\text { Upaya meningkatkan keaktifan belajar } \\
\text { siswa dengan metode kompetisi di kelas } \\
\text { III SDN Kedokan }\end{array}$ \\
\hline \multirow{2}{*}{ IV } & \multirow{2}{*}{$\begin{array}{l}\text { Hasil belajar } \\
\text { matematika }\end{array}$} & $\begin{array}{l}\text { Pembelajaran } \\
\text { matematika } \\
\text { realistik }\end{array}$ & $\begin{array}{l}\text { Upaya meningkatkan kemampuan belajar } \\
\text { siswa dengan pembelajaran matematika } \\
\text { realistik di kelas IV SDN Cibogo }\end{array}$ \\
\hline & & $\begin{array}{l}\text { Permainan kartu } \\
\text { bilangan }\end{array}$ & $\begin{array}{l}\text { Upaya meningkatkan kemampuan belajar } \\
\text { siswa dengan permainan kartu bilangan di } \\
\text { kelas IV SDN Kedokan }\end{array}$ \\
\hline \multirow{2}{*}{ V } & Hasil belajar & $\begin{array}{l}\text { Metode mix and } \\
\text { match }\end{array}$ & $\begin{array}{c}\text { Peningkatan hasil belajar siswa dengan } \\
\text { metode mix and match di kelas V SDN } \\
\text { Mekarwangi }\end{array}$ \\
\hline & Minat belajar & Penggunaan lagu & $\begin{array}{c}\text { Penggunaan lagu untuk meningkatkan } \\
\text { minat belajar siswa di kelas V SDN } \\
\text { Kedokan }\end{array}$ \\
\hline \multirow{2}{*}{ VI } & Hasil belajar & Metode permainan & $\begin{array}{l}\text { Peningkatan hasil belajar siswa pada } \\
\text { materi FPB dan KPK dengan metode } \\
\text { permainan di kelas VI SDN Cibogo }\end{array}$ \\
\hline & Minat belajar & Metode permainan & $\begin{array}{l}\text { Peningkatan minat belajar siswa pada } \\
\text { materi FPB dan KPK dengan metode } \\
\text { permainan di kelas VI SDN Kedokan }\end{array}$ \\
\hline
\end{tabular}

Pada akhir pelatihan, guru diminta untuk menuliskan draf proposal PTK. Draf ini disusun dengan sangat sederhana yaitu menuliskan poin-poin penting yang menjadi komponen Proposal PTK. Berdasarkan kesepakatan, draf ini akan dikumpulkan pada pertemuan berikutnya. Sebelum pelatihan diakhiri, narasumber memberikan kesempatan bagi guru-guru untuk bertanya, namun tidak ada pertanyaan lebih lanjut mengenai tugas mengisi draf proposal PTK ini. 
Selanjutnya pertemuan kedua dilaksanakan di SDN Mekarwangi. Pelatihan dimulai pada pukul 10.00 sampai dengan 14.00. Setelah pelatihan dibuka, narasumber menanyakan tugas menulis draf proposal PTK. Dari 11 kelompok dengan judul PTK seperti pada tabel 3 yang sudah dihasilkan, hanya 1 kelompok yang mengumpulkan draf proposal PTK. Hampir semua kelompok belum selesai mengisi format draf proposal PTK. Ketika narasumber bertanya mengenai hal ini, mereka menyatakan bahwa mereka masih bingung dalam pengisiannya. Oleh karena itu, narasumber menjelaskan kembali bagaimana cara mengisi format tersebut. Selain menjelaskan, narasumber juga memberikan contoh secara langsung sehingga setiap kelompok dapat secara langsung mengikuti cara yang dicontohkan. Setelah semua peserta paham, penulisan draf proposal kembali menjadi tugas dan dikumpulkan melalui email paling lambat Senin, 10 September 2018. Narasumber melanjutkan penjelasan materi mengenai pengembangan instrumen penelitian tindakan kelas. Melalui arahan narasumber melalui tanya jawab, guru dapat menentukan instrument apa saja yang harus mereka kembangkan untuk dapat melaksanakan PTK yaitu Rencana Pelaksanaan Pembelajaran (RPP), lembar observasi pelaksanaan pembelajaran, instrumen tes atau non tes yang diawali dengan pembuatan kisi-kisi. Pada penjelasan materi ini, tidak banyak guru yang bertanya karena pada dasarnya apa yang akan dikembangkan merupakan bagian dari pekerjaan mereka sehari-hari. Oleh karena itu pada akhir pelatihan, narasumber memberikan tugas untuk mengembangkan instrumen PTK dan dikumpulkan melalui email pada minggu ketiga September 2018. Sampai dengan Kamis, 20 September 2018 baru 1 kelompok yang mengirimkan instrumen penelitian tindakan kelas secara lengkap.

DISKUSI

Kekurangan umum para guru dalam menuliskan draf proposal PTK adalah pada bagian fokus tindakan dan teknik pengumpulan data. Pada bagian pendahuluan proposal PTK, beberapa guru tidak menuliskan nama pengarang yang teorinya digunakan sebagai landasan teori dalam latar belakang. Ada juga guru yang tidak menggunakan pengalaman pribadi sebagai guru sebagai landasan empiris dalam latar belakang. Selanjutnya rata-rata guru kurang tepat dalam menuliskan tujuan dan manfaat penelitian. Biasanya tujuan penelitian dirumuskan seperti tujuan penelitian kuantitatif sedangkan kalimat yang disusun dalam manfaat penelitian lebih tepat dikatakan sebagai manfaat pembelajaran dan bukan manfaat penelitiannya.

Pada bagian kajian teori, kebanyakan guru kurang lengkap dalam menuliskan hasil kajian teori yang digunakan sebagai acuan dalam penelitiannya. Hal ini dikarenakan, guru tidak banyak yang memiliki pustaka yang relevan dengan topik yang akan diteliti. Guru melakukan kajian teori dengan memanfaatkan internet sebagai sumber utama. Namun hal ini hanya dilakukan oleh guru yang memang sudah terbiasa dengan internet. Bagi guru yang tidak bisa atau tidak terbiasa dengan internet, tidak dapat melakukan kajian teori. Oleh karena itu mereka menuliskan teori berdasarkan pengetahuan dan pemahaman mereka sendiri.

Pada bagian metode penelitian, biasanya guru tidak tepat dalam menuliskan waktu penelitian. Menurut pemahaman mereka, waktu penelitian adalah waktu dimana mereka melaksanakan pembelajaran siklus. Guru juga sering kurang tepat dalam menuliskan definisi operasionalnya. Guru yang menuliskan kajian teori dengan menuliskan nama penulisnya akan menuliskan hal yang sama di definisi operasional. Selain itu, kadang guru menuliskan definisi operasional masih kurang operasional kalimatnya. Kebanyakan guru menuliskan penjelasan dan bukan definisi. Selanjutnya pada fokus tindakan, kebanyakan guru menuliskan fokus tindakan dengan tidak melihat penelitian yang akan dilaksanakan. Ada guru yang merancang fokus tindakan sudah mengacu pada topik yang akan diteliti namun salah dalam menentukan tindakannya karena tidak sesuai dengan karakteristik metode penyelesaian masalahnya. Misalkan proposal PTK yang berjudul "Upaya 
meningkatkan kemampuan belajar siswa dengan pembelajaran matematika realistik di kelas IV SDN Cibogo", guru menuliskan fokus tindakan pada siklus I adalah melakukan pembelajaran matematika realistik secara individu. Padahal salah satu karaktetistik pembelajaran interaktivitas baik interaksi antara guru dengan siswa maupun siswa dengan siswa. Oleh karena itu pendekatan pembelajaran matematika realistik tidak mungkin dilakukan siswa secara individu.

Pada bagian akhir draf proposal PTK, yaitu daftar pustaka, banyak guru yang tidak menuliskan pustaka yang digunakan dalam melakukan PTK. Hal ini disebabkan karena guru melakukan kajian teori tidak melalui buku teks melainkan dari internet. Beberapa guru mencoba menuliskan beberapa buku yang digunakan oleh penulis yang tulisannya ada di internet dan mereka gunakan sebagai acuan penelitian.

\section{KESIMPULAN DAN SARAN}

Berdasarkan hasil pelatihan dan pendampingan terhadap guru SD di SDN Kedokan, Cibogo, dan Mekar Wangi dalam melaksanakan Penelitian Tindakan Kelas (PTK) dapat disimpulkan beberapa hal. Pertama, guru perlu membekali diri dengan pengetahuan baik mengenai strategi, model, pendekatan atau metode pembelajaran yang dapat digunakan sebagai alternatif pemecahan masalah pembelajaran di kelas. Kedua, guru perlu berlatih secara kontinu dalam menggali permasalahan pembelajaran dan memecahkan masalah tersebut melalui PTK. Ketiga, guru juga perlu mengembangkan Rencana Pelaksanaan Pembelajaran (RPP) yang mengacu pada strategi, model, pendekatan atau metode pembelajaran tertentu sebagai instrumen Penelitian Tindakan Kelas.

Oleh karena itu disarankan agar guru bekerjasama dengan lembaga pendidikan seperti Program Studi Pendidikan Guru SD Unika Atma Jaya untuk melaksanakan penelitian kolaboratif bersama sehingga diharapkan guru semakin terampil dalam melaksanakan penelitian khususnya Penelitian Tindakan Kelas (PTK).

\section{DAFTAR PUSTAKA}

Asmarani, N. 2014. Peningkatan kompetensi professional guru di sekolah dasar. Volume 2 Nomor 1, Juni 2014 | Bahana Manajemen Pendidikan | Jurnal Administrasi Pendidikan

Cahyana, A. 2010. Pengembangan Kompetensi Profesional Guru dalam Menghadapi Sertifikasi. Jurnal Pendidikan dan Kebudayaan, Volume 16, Nomor 1, Januari 2010.

Departemen Pendidikan Nasional, 2003. Undang-Undang Nomor 20 Tahun 2003, Tentang Sistem Pendidikan Nasional, Jakarta: Depdiknas.

Departemen Pendidikan Nasional, 2005. Undang-Undang Nomor 14 Tahun 2005, Tentang Guru dan Dosen, Jakarta: Depdiknas.

Herlina, N. 2008. Persepsi, Sikap, dan Norma Subjektif Terhadap KB Kontrasepsi Mantap (Penelitian Komparasi Pada Suami Akseptor KB Kontap dan Suami Bukan Akseptor KB Kontap di Kecamatan Bulu Kabupaten Rembang). Semarang: UNNES

Iskandar. 2012. Penelitian tindakan kelas. Jakarta: Referensi.

Mulyasa, E. 2005. Menjadi guru profesional menciptakan pembelajaran kreatif dan menyenangkan. Bandung: Remaja Rosdakarya.

Mulyasa. 2009. Menjadi Guru Profesional. Bandung: Remaja Rosdakarya

Pidarta, Made. 2011. Manajemen Pendidikan Indonesia. Jakarta: Rineka Cipta

Semiawan, C. 2007. Kebijakan pendidikan era otonomi daerah. Jakarta: raja Grafindo Persada Subyantoro. 2010. Pelaksanaan dan pelaporan penelitian tindakan kelas. Makalah yang disajikan pada Seminar dan Lokakarya Nasional "Penelitian Tindakan Kelas dalam Perspektif 
Etnografi" yang diselenggarakan oleh Program Pascasarjana program Studi Magister Linguistik Universitas Diponegoro

Suparno, P. 2008. Action research. Riset tindakan untuk pendidikan. Jakarta: Grasindo

Sumini. 2010. Penelitian tindakan kelas dan pengembangan profesi guru. Http://www/usd.ac.id/ Diakses 24 April 2017

Suyanto dan Djihad, A. 2012. Bagaimana menjadi calon guru dan guru professional. Yogyakarta: Multi Pressindo

Wardani,dkk. 2008. Penelitian tindakan kelas. Jakarta: Universitas Terbuka

Zamania. (2009). Upaya peningkatan kompetensi pedagogik guru dalam proses belajar mengajar di Raudlatul Athfal Al-Ikhlas Sukodadi Lamongan. Skripsi. Malang: Fakultas Tarbiah Universitas Islam Negeri Maulana Malik Ibrahim Malang 